\title{
ベトナムにおける抗菌性物質の環境水中残留実態
}

\author{
原田和生
}

\section{Antibiotic Residue in Environmental Water in Vietnam}

\author{
Kazuo Harada \\ Graduate School of Pharmaceutical Sciences, Osaka University; 1-6 Yamadaoka, Suita, Osaka 565-0871, Japan.
}

(Received July 21, 2017)

\begin{abstract}
The increasing prevalence of antimicrobial resistance (AMR) has caused intractable infections worldwide. Nearly $50 \%$ of the healthy population of Southeast Asia carries extended-spectrum $\beta$-lactamase (ESBL)-producing Escherichia coli. The overuse of antimicrobial agents in the agriculture, aquaculture, and medical care sectors causes environmental pollution, facilitating the spread of AMR. However, there is a lack of data pertaining to antimicrobial residues in environmental water in such regions. We investigated a total of 49 chemicals, including $\beta$-lactams, sulfonamides, quinolones, and tetracyclines. Water samples were collected from rivers in city centers, and ponds in livestock and aquaculture farms, in Ha Noi, Thai Binh, and Can Tho in Vietnam. We detected antimicrobial agents at 87 of 111 sampling sites $(78.4 \%)$. Among the target analytes, sulfamethoxazole, sulfamethazine, trimethoprim, cephalexin, and ofloxacin were detected frequently. The residual levels of each antimicrobial agent ranged from 0.1 to $10000 \mathrm{ng} / \mathrm{L}$. Moreover, we detected multi-drug resistant $E$. coli in fishes sampled from these rivers, suggesting unwanted effects of antimicrobial residues in the environment.
\end{abstract}

Key words_ antimicrobial agent; antimicrobial resistance; environmental pollution; Vietnam

\section{1.はじめに}

近年，抗菌性物質が効かない薬剂耐性菌の発生・ 曼延が問題となっている。WHO は 2011 年 4 月 7 日を World Health Day として“antimicrobial resistance’’のキャンペーンを掲げ，国際社会が協 調し対策に取り組む必要性を説き,1) 2015 年には “Global Action Plan”を示し，加盟各国にアク ションプラン策定を要請した. ${ }^{2)} 2016$ 年の G7 伊勢 志摩サミット首脳宣言の中にもこの問題が盛り込ま れたことは記憶に新しい. ${ }^{3)}$

従来，薬剂耐性菌について問題の中心となつてい たのは，抗菌性物質の使用頻度が高く，かつ，免疫 機能が低下した患者が多く存在している病院内での 発生・䒤延，いわゆる，院内感染である。1980 年 代，代表的な薬剤耐性菌メチシリン黄色ブドウ球菌 (Methicillin-resistant Staphylococcus aureus; MRSA)

大阪大学大学院薬学研究科（T565-0871 大阪府吹田市 山田丘 1-6)

e-mail: harada6@phs.osaka-u.ac.jp

本総説は, 日本薬学会第 137 年会シンポジウムS46で

発表した内容を中心に記述したものである.
が社会問題化した際には，各地の病院で MRSA が 検出され, 多くの施設で院内感染対策に取り組み始 めた. ${ }^{4)}$ 一方，畜産，養殖においても抗菌性物質の 使用量は多く，特に畜産場から薬剤耐性菌が分離さ れる頻度は極めて高い。このような耐性菌が環境あ るいは食品を介して，市中健常人に伝播しているこ とを示唆する報告も増えている，したがって，薬剤 耐性菌は病院のみならず, ヒトが生活する環境にあ りふれた存在となっていると言える.

薬剤耐性菌の蔓延は世界中で問題となっている が，特にアジア諸国では深刻化している。中山 は, タイ, ラオス, ベトナムの市中健常人の extended-spectrum $\beta$-lactamase（ESBL）産生大腸菌保菌率 は 47.5-64.1\%と極めて高いことを示しており, ${ }^{5)} ま$ た，カルバペネム耐性腸内細菌科細菌が市中から検 出されている事例も報告されている.これらの菌が 直接，重篤な感染症を惹起するわけではないが，薬 剂而性遺伝子が病原菌に伝播し，より重篤な難治性 感染症が発生するリスクも十分考えられる．アジア 諸国で薬剤耐性菌が蔓延している原因として，医 療・音水産業における抗菌性物質の過剩使用に伴う 
(A)

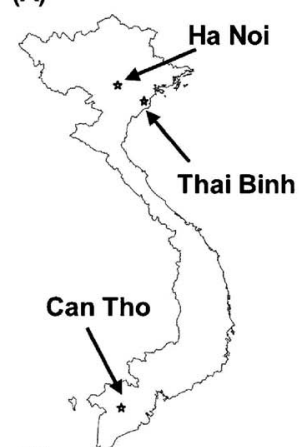

(C)

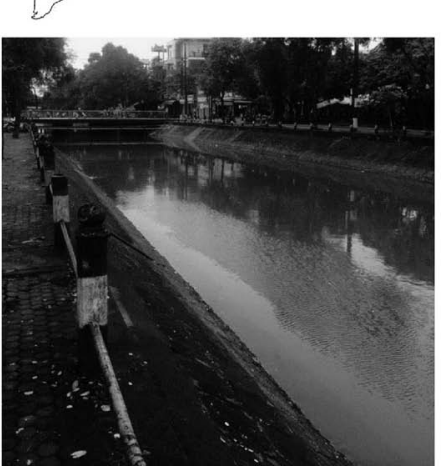

(B)

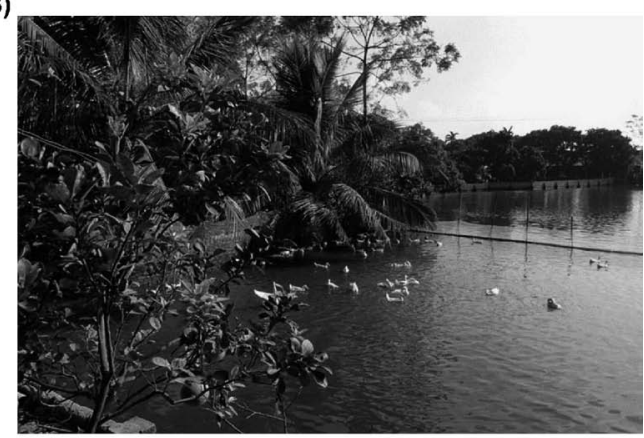

(D)

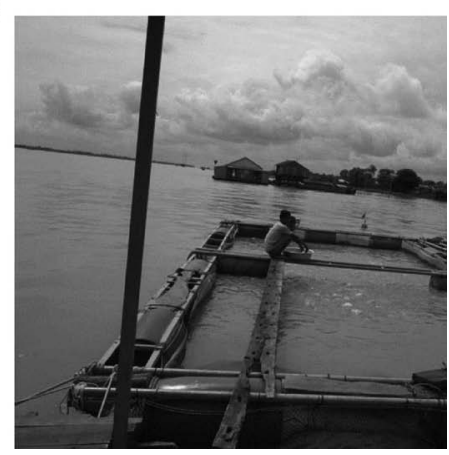

Fig. 1. Overall Map of Vietnam (A) and Photographs of Typical Sampling Sites (B-D)

(B) Farmer pond (Ha Noi), (C) River in city center (Thai Binh), (D) Aquaculture cage in river (Can Tho).

環境污染により耐性菌が発生・維持される可能性が 考えられるが，その詳細な実態は不明な点が多い.

筆者は 2011 年から 2017 年 3 月まで，科学技術振 興機構 (Japan Science and Technology Agency; JST), 日本医療研究開発機構 (Japan Agency for Medical Research and Development; AMED), と国 際協力機構 (Japan International Cooperation Agency； JICA）が共同で実施する地球規模課題対 応国際科学技術協力プログラム (Science and Technology, Research Partnership for Sustainable Development；SATREPS）に採択された「薬剤耐性細 菌発生機構の解明と食品管理における耐性菌モニ夕 リングシステムの開発」（代表 山本容正 大阪大学 招へい教授）のプロジェクトに参画し，ベトナムに おける食品，環境中における抗菌性物質残留実態の 調査を行つた。本稿ではその結果を概説し，今後の 課題について私見を述べたい.

\section{2. ベトナムの 3 地域における調査結果}

筆者は，畜産業の盛んな Ha Noi 市の Chu Minh 村 Ba Vi 地区, 紅河デルタ地域の中心都市 Thai Binh 市市街地, 及び郊外 Nguyen Xa 地区, キャッ トフィッシュやティラピアなどの水産養殖業が盛ん で, 海外への輸出量も多いメコンデル夕地域の中心
都市 Can Tho 市及びその周辺の An Giang 市, Dong Thap 市, Vinh Long 市を調査対象とした (Fig. 1)。採取した水に含まれる抗菌性物質を固相 抽出により精製, 濃縮後, 液体クロマトグラフィー/ タンデム質量分析（LC/MS/MS）を用いて測定し た. 解析対象としたのは, $\beta$-lactam, cephalosporin, sulfonamide, quinolone, tetracycline など計 49 化合 物である. ${ }^{6,7)}$

全 111 地点中なんらかの抗菌性物質が検出された のは 87 力所 $(78.4 \%)$ であった。 その内訳を Table 1 に示す. 高頻度で検出された化合物はサル ファ系の sulfamethoxazole (SMX), sulfamethazine (SMT, sulfadimidine とも呼ばれる)，葉酸代謝拮抗 剂の trimethoprim (TMP), セフェム系の cephalexin, キノロン系の ofloxacin であった. TMP はサル ファ剂との合剂 ST 剂として使用されることが多い ことから，同程度の検出頻度となったと考えられ る. 上述の化合物はほぼすべてのサイトで共通して 高頻度で検出されたが, 検出化合物にはいくぶんか 地域差がみられた。 また，SMT の代謝物である $N$ acetylsulfamethazine (AceSMT) も高頻度に検出さ れており, 特に家畜の粪尿の混入の頻度が極めて高 いことが窥えた。例えば，Ha Noi 市 Chu Minh 村 
Table 1. Detection Ratios and Detection Ranges at Sampling Sites

\begin{tabular}{|c|c|c|c|c|c|c|c|c|c|c|}
\hline \multirow{2}{*}{ Site } & \multirow{2}{*}{ Location } & \multicolumn{9}{|c|}{ Detection ratio (\%) and detection range (minimum-maximum, $\mathrm{ng} / \mathrm{L}$ ) } \\
\hline & & SMX & SMT & AceSMT & SDZ & OFLX & NLDX & FLMQ & CEX & TMP \\
\hline Ha Noi & $\underset{(25)^{\dagger}}{\text { Farm pond }}$ & $\begin{array}{c}84 \% \\
7.3-2017\end{array}$ & $\begin{array}{c}92 \% \\
6.3-6621\end{array}$ & $\begin{array}{c}96 \% \\
0.7-3005\end{array}$ & $\begin{array}{c}56 \% \\
0.9-474\end{array}$ & $\begin{array}{c}16 \% \\
0.2-0.9\end{array}$ & $\begin{array}{c}20 \% \\
4.3-17.4\end{array}$ & $\begin{array}{c}100 \% \\
1.7-245\end{array}$ & $\begin{array}{c}24 \% \\
0.4-24\end{array}$ & $\begin{array}{c}48 \% \\
0.8-78\end{array}$ \\
\hline \multirow{2}{*}{ Thai Binh } & $\begin{array}{c}\text { Farm pond } \\
(33)\end{array}$ & $\begin{array}{c}24 \% \\
1.5-189\end{array}$ & $\begin{array}{c}9 \% \\
1.8-5.5\end{array}$ & $\begin{array}{c}6 \% \\
0.3-26\end{array}$ & $0 \%$ & $\begin{array}{c}9 \% \\
1.0-2.7\end{array}$ & $0 \%$ & $\begin{array}{c}6 \% \\
1.5-2.5\end{array}$ & $\begin{array}{c}21 \% \\
1.9-17\end{array}$ & $\begin{array}{c}12 \% \\
4.7-56\end{array}$ \\
\hline & $\begin{array}{l}\text { City river } \\
\text { (10) }\end{array}$ & $\begin{array}{c}100 \% \\
3.0-781\end{array}$ & $\begin{array}{c}70 \% \\
3.1-34\end{array}$ & $\begin{array}{c}30 \% \\
1.2-2.7\end{array}$ & $0 \%$ & $\begin{array}{c}50 \% \\
1.3-58\end{array}$ & $\begin{array}{c}30 \% \\
5.4-18\end{array}$ & $\begin{array}{c}10 \% \\
19\end{array}$ & $\begin{array}{c}60 \% \\
3.4-11\end{array}$ & $\begin{array}{c}50 \% \\
4.8-70\end{array}$ \\
\hline \multirow{3}{*}{ Can $\mathrm{Tho}^{6,7)}$} & $\begin{array}{c}\text { Farm pond } \\
(4)\end{array}$ & $\begin{array}{c}50 \% \\
1.9-14\end{array}$ & $\begin{array}{c}50 \% \\
10-165\end{array}$ & $\begin{array}{c}50 \% \\
3.8-49\end{array}$ & $\begin{array}{c}75 \% \\
6.6-113\end{array}$ & $0 \%$ & $0 \%$ & $0 \%$ & $\begin{array}{c}50 \% \\
14-127.2\end{array}$ & $\begin{array}{c}25 \% \\
2.0\end{array}$ \\
\hline & $\begin{array}{c}\text { River } \\
\text { (16) }\end{array}$ & $\begin{array}{c}94 \% \\
0.2-47\end{array}$ & $\begin{array}{c}25 \% \\
0.5-15\end{array}$ & $\begin{array}{c}25 \% \\
1.3-2.3\end{array}$ & $\begin{array}{c}13 \% \\
0.3-2.8\end{array}$ & $0 \%$ & $0 \%$ & $0 \%$ & $\begin{array}{c}31 \% \\
1.7-19\end{array}$ & $\begin{array}{c}31 \% \\
1.0-3.2\end{array}$ \\
\hline & $\begin{array}{l}\text { Aquaculture } \\
\text { pond (10) }\end{array}$ & $\begin{array}{c}90 \% \\
0.9-642\end{array}$ & $\begin{array}{c}60 \% \\
2.0-14.3\end{array}$ & $\begin{array}{c}50 \% \\
1.3-5.3\end{array}$ & $0 \%$ & $0 \%$ & $0 \%$ & $0 \%$ & $\begin{array}{c}40 \% \\
1.7-16\end{array}$ & $\begin{array}{c}40 \% \\
1.5-3.3\end{array}$ \\
\hline
\end{tabular}

${ }^{\dagger}$ Numbers in parentheses show sample numbers. Abbreviation; SMX: sulfamethoxazole, SMT: sulfamethazine, AceSMT: $N$-acetylsulfamethazine, SDZ: sulfadiazine, OFLX: ofloxacin, NLDX: nalidixic acid, FLMQ: flumequine, CEX: cephalexin, TMP: trimethoprim.

Ba Vi 地区ではオールドキノロンである flumequine が 100\%で検出されたのに対し，他のサイトではほ ぼ検出されなかった。

人畜共通感染症及びその起因菌の薬剂耐性化を防 ぐ観点から，一般的に使用する抗菌性物質はヒトと 家畜とで使い分けがなされている，一方，魚介類に ついては，ヒトと密接に接触することがないため, 家畜ほど厳密な使い分けがなされていないのが現状 である。実際，サルファ剂に関しては世界中で, SMX がヒト，魚介類，SMT が牛や豚などの家畜に 対して，区別して使用されている。 これらのことか ら多くのサイトでヒト，家畜に使用された抗菌性物 質がともに環境中に放出されていることが窥える.

高頻度に検出された SMX, SMT, AceSMT の検 出濃度は Ha Noi 農村の池, Thai Binh 中心部の河 川では $10^{2}-10^{3} \mathrm{ng} / \mathrm{L}$ の範囲に及び，特に Ha Noi 農 村の池では検出された抗菌性物質の濃度を積算する と $10^{3}-10^{4} \mathrm{ng} / \mathrm{L}$ に及ぶケースも多く見受けられ た. 一方, Thai Binh 郊外の農家の池, メコンデル 夕地域では $10^{0}-10^{2} \mathrm{ng} / \mathrm{L}$ の範囲が多く, 上述のサ イトに比較して低濃度となる傾向がみられた。類似 の研究で, Hoa らはべトナム北部の農家の養豚場 付近の池から SMTを 475-6662 ng/L, 市街地の水 路から SMX を 612-4330 ng/L で検出している. ${ }^{8}$ また, Nguyen らはメコンデル夕周辺の環境水から, SMX, TMP をそれぞれ 1-239, 1-330 ng/L で検出

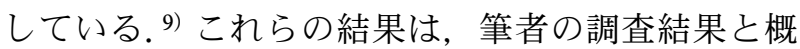
ね一致している.
多くの抗菌性物質の臨床分離株に対する最小増殖 阻止濃度は数 $\mu \mathrm{g} / \mathrm{mL}$ であり，これに比べ，上述の 環境中残留濃度は，少なくとも $10^{2}$ 倍の開きがあ る。したがって, 環境中において, 薬剤感受性菌が 残留抗菌性物質により殺菌，あるいは増殖が抑制さ れ，自然界に元来存在していた薬剤耐性菌が選択さ れるといつた事象が生じている可能性は考え難い. しかし, 近年, 実験室レベルでの検証ではあるが, 抗菌性物質の低濃度長期暴露により突然変異頻度が 増加し, 薬剂耐性も獲得し易くなるという報告も増 えており，10,11）環境中でも，低濃度の抗菌性物質で もなんらかの機構により, 薬剤耐性菌の発生が促進 されていることが推測される，実際，筆者の調査対 象の中では検出濃度が低かったメコンデル夕地域で 養殖魚の腸管から分離された ESBL 産生大腸菌の 薬剤感受性を調べたところ, 最も耐性化率が高かっ

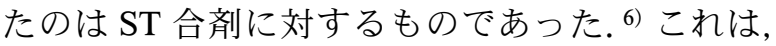
当該地域でほぼすべての試料から検出された薬剤が SMX であったことから，環境中の残留抗菌性物質 の影響は皆無とは言えないことが推察される．さら に様々な作用機序の抗菌性物質が同時に混在するよ うな環境での薬剤耐性化については十分な検証がな されておらず，今後の研究の課題と言える.

\section{3. 抗菌性物質分解物の残留}

上記のような調査と同時に，サンプリング地点周 辺の診療所，農家に対し，抗菌性物質使用について インタビュー調査も実施した．使用記録を残してい る診療所，農家が極めて少なく，信憑性に欠ける点 
も多かつたが，薬剤のパッケージから見い出される 頻度が高い成分には ampicillin (ABPC) や amoxicillin (AMPC) といつた $\beta$-lactam 系抗生物質が含 まれていた。しかしながら，環境水の測定でこれら の物質が検出された事例は極めて少なかった。 そこ で，ABPC や AMPC が環境中に排出された後，分 解されて得られる物質 ${ }^{12,13)}$ を測定したところ, ABPC の分解産物である 2-hydroxy-3-phenylpyrazine (HPP) が高頻度に検出された. ${ }^{14)}$ 当該物質は ABPC だけでなく, 同一の部分骨格を持つ cephalexin からも生成し，また，ABPCのプロド ラックも数多く存在するため, $\mathrm{HPP}$ が ABPC 特異 的な分解産物とは言えない。しかし，少なくとも HPP はヒトや家畜の体内で ABPC が代謝され排出 されるものとしては報告されておらず，当該物質が 環境中から検出されたことは，未変化体の ABPC 若しくはそれと同一の部分骨格を持つ抗菌性物質が 環境中に排出されたことを示していると考えられ る.このことは, 測定結果以上に, 多種類, 高濃度 の抗菌性物質が環境中に放出されていることを示唆 している.

\section{4. ベトナム国内で流通する生鮮食品の残留抗菌} 性物質

プロジェクトではベトナム国内で流通する肉, 魚 介類, 鶏卵などの生鮮食品の抗菌性物質の残留実態 も調查してきた。総計約 1400 検体を分析し，12\% 程度からなんらかの抗菌性物質が検出された. ${ }^{15-17)}$ 世界各国，最大残留濃度（maximum residual level; MRL）が規制值として設定されており，ベトナム においても食品と抗菌性物質の組み合わせによって いくつか設定されている。これらの規制值は日本や 欧米に倣つているが，その規制值を大きく上回る検 体もいくつかみられた。 ベトナムは世界有数の農水 産物の輸出国であり, 海外に輸出される食品は非常 に厳しく検査がなされているが，国内で流通する食 品については, 検査体制も緩く, 高頻度で残留抗菌 性物質が検出されているのが現状である，MRL は 人体に対する直接的な毒性を鑑みた規制值であるた め, 薬剤耐性菌の発生・曼延のリスクを評価できる ものでは全くないが，少なくとも MRL を超過する 生鮮食品が流通する状況というのは，休薬期間が遵 守されていないなど，生産体制，品質管理体制が不 適切であることを示しており，管理，監視体制の強
化が重要である.

\section{5. おわりに}

筆者が参画したプロジェクトでベトナムの環境及 び食品は広く抗菌性物質に污染されており，そこか らは薬剂耐性菌も高頻度に分離されることが明らか になった。これらが薬剤耐性菌のリザーバーとなつ ていることはほぼ間違いないと思われる。 また，べ トナムに限らず，アジア諸国の多くが同様の状況に あると推測される。

近年はヒト及び動物の健康，農業，食品，環境な ぞ分野横断で対策に取り組む「ワン・ヘルス・アプ ローチ」という言葉が盛んに用いられるようになつ てきている。これを着実に推進するために，抗菌性 物質の残留実態のモニタリング，及び抗菌性物質の 分解経路，分解産物の環境影響などの基礎的・科学 的知見の集積の必要性はより高まっている.

謝辞本稿で示した筆者の研究の一部は，地球 規模課題対応国際科学技術協力プログラム (Science and Technology, Research Partnership for Sustainable Development; SATREPS)「薬剤而性細 菌発生機構の解明と食品管理における耐性菌モ二夕 リングシステムの開発」（代表 山本容正 大阪大学 招へ(教授), 及びクリタ水・環境科学振興財団助 成金（15B011）の助成を受けて実施されたもので ある、また，本研究をともに実施した Nguyen Van Sy氏，浅山 恵氏，割鞘美苗氏，さらに，研究を サポート頂いた大阪大学大学院薬学研究科 平田收 正教授, 山本容正招へい教授, 中山達哉博士（現, 国立医薬品食品衛生研究所), 大阪府立大学大学院 生命環境科学研究科 日根野谷 淳博士を始め, 大 阪健康安全基盤研究所, ベトナム国立栄養院, タイ ビン医科薬科大学，カントー大学の共同研究者に厚 く御礼を申し上げます。

\section{利益相反＼cjkstart開示すべき利益相反はない.}

\section{REFERENCES}

1) Leung E., Weil D. E., Raviglione M., Nakatani H., Bull. World Health Organ., 89, 390-392 (2011).

2) World Health Organization, Draft Global action plan on antimicrobial resistance 
WHA68.7, 2015.

3) Ministry of Foreign Affairs of Japan, G7 IseShima Vision for Global Health, Annexes 2 of G7 Ise-Shima Leaders' Declaration, 2016.

4) Shiba K., Jpn. J. Environ. Infect., 31, 1-9 (2016).

5) Nakayama T., Ueda S., Huong B. T. M., Tuyen L. D., Komalamisra C., Kusolsuk T., Hirai I., Yamamoto Y., Infect. Drug Resist., 8, 1-5 (2015).

6) Hon N. T. N., Hoa T. T. T., Thinh N. Q., Hinenoya A., Nakayama T., Harada K., Asayama M., Warisaya M., Hirata K., Phuong N. T., Yamamoto Y., Fish Pathol., 51, S75-S82 (2016).

7) Nakayama T., Hoa T. T. T., Harada K., Warisaya M., Asayama M., Hinenoya A., Lee J. W., Phu T. M., Ueda S., Sumimura Y., Hirata K., Phuong N. T., Yamamoto Y., Environ. Pollut., 222, 294-306 (2017).

8) Hoa P. T. P., Managaki S., Nakada N., Takada H., Shimizu A., Anh D. H., Viet P. H., Suzuki S., Sci. Total Environ., 409, 2894-2901 (2011).

9) Nguyen Dang Giang C., Sebesvari Z., Renaud F., Rosendahl I., Hoang Minh Q., Amelung W., PLoS One, 10, e0131855 (2015).

10) Kohanski M. A., DePristo M. A., Collins J. J., Mol. Cell, 37, 311-320 (2010) .

11) Andersson D. I., Hughes D., Nat. Rev. Microbiol., 12, 465-478 (2014).

12) Gozlan I., Rotstein A., Avisar D.,
Chemosphere, 91, 985-992 (2013).

13) Mitchell S. M., Ullman J. L., Teel A. L., Watts R. J., Sci. Total Environ., 466-467, 547-555 (2014).

14) Sy N. V., Harada K., Asayama M., Warisaya M., Dung L. H., Sumimura Y., Diep K. T., Ha L. V., Thang N. N., Hoa T. T. T., Phu T. M., Khai P. N., Phuong N. T., Tuyen L. D., Yamamoto Y., Hirata K., Chemosphere, 172, 355-362 (2017).

15) Yamaguchi T., Okihashi M., Harada K., Konishi Y., Uchida K., Do M. H. N., Bui H. D. T., Nguyen T. D., Nguyen P. D., Chau V. V., Dao K. T. V., Nguyen H. T. N., Kajimura K., Kumeda Y., Bui C. T., Vien M. Q., Le N. H., Hirata K., Yamamoto Y., J. Agric. Food Chem., 63, 5141-5145 (2015).

16) Uchida K., Konishi Y., Harada K., Okihashi M., Yamaguchi T., Do M. H. N., Bui L. T., Nguyen T. D., Nguyen P. D., Khong D. T., Tran H. T., Nguyen T. N., Le H. V., Chau V. V., Dao K. T. V., Nguyen H. T. N., Kajimura K., Kumeda Y., Pham K. T., Pham K. N., Bui C. T., Vien M. Q., Le N. H., Dang C. V., Hirata K., Yamamoto Y., J. Agric. Food Chem., 64, 6133-6138 (2016).

17) Yamaguchi T., Okihashi M., Harada K., Konishi Y., Uchida K., Do M. H. N., Bui L. T., Nguyen T. D., Phan H. B., Bui H. D. T., Nguyen P. D., Kajimura K., Kumeda Y., Dang C. V., Hirata K., Yamamoto Y., J. Environ. Sci. Health, B, 52, 430-433 (2017). 